\title{
CZECH MUSIC SEMIOLOGY
}

To say "music semiology" already means a certain classification. With its help, it's possible to interpret the syntax of music and the process of structuring a musical work; semiology thus becomes part of music theory. Semiology (at least as a music-oriented pragmatic system) can be an inspiration to music sociology, historiography, ethnomusicology. Not even the emancipatory tendencies of the last few decades have deprived semiology of its links to aesthetics. It is still true that questions of signs and meanings in music is one of the key problems of music aesthetics. Its study offers three possible approaches with, of course, a range of varieties and cross-currents. The most radical approach denies that music carries any sign, or even a communicative status. A second approach, let's call it "nonsemiotic formalism", connects the meaning of a work with the way it is structured and modelled at all levels. The third approach acknowledges that music is a sign structure of its own kind and that musical signs have specific meanings.

Speaking about signs and meanings doesn't necessarily make us music semiologists. The whole intricate issue can be usefully described from a view outside the actual music-semiotic discourse, as has been done so for instance by Carl Dahlhaus, Hans Heinrich Eggebrecht or Peter Faltin. On the other hand there were authors like Zofia Lissa, Vladimír Karbusický, Christian Kaden or Jiř́ Fukač, who essentially recognized the need of musical semiology (or specifically the semantics of music), who were aware of the fact that the results of semiotic interpretation don't always sound convincing enough. This may be why these authors, with their own emphatic style, drew attention to some difficulties and possible mistakes arising from the application of this method.

When Jaroslav Volek (1981) in his study Musical Structure as Sign and Music as a System of Signs ${ }^{1}$, published in Opus musicum, described a possible methodology for Czech music semiology, he expressed in it not only his wishes and expectations, but at the same time a conviction that the application of principles of the general theory of signs and linguistic theories would lead to the solution of

1 VOLEK, Jaroslav. Hudební struktura jako znak a hudba jako znakový systém. Opus musicum, XIII/5, 6, 10 (1981), s. 129-142, 161-174, 289-295. 
the question of the conditions under which music is able to contain specific meanings or refer to something beyond itself. All this was nurtured by the experience of a musicologist who showed an ambition to understand the meaning of things and fully grasp the phenomenon in question, hand in hand with a scepticism that warns against premature interpretations.

In his study Volek compares semiotic discourse to the noise of a big bazaar, which means the inflationary invasion of several methodologies and interpretations. Despite Volek's evaluation being a criticism of the situation current at the time, it is still true that there is no unique "leading" conception of semiology. In this field there is a range of scholarly approaches and schools. The statement that semiology today presents a methodologically non-homogeneous subject, fragmented into a range of fields, certainly doesn't sound too surprising. And this is completely accurate also if one refers to Czech research into the subject (Czech is in many cases synonymous to Czechoslovak).

So what is Czech semiology like? If the credibility and legitimacy of a subject depends on the number of its users, then it will certainly count as a marginal conception. This type of theory was developed in Czechoslovakia from the end of the $50 \mathrm{~s}$. Since the $70 \mathrm{~s}$ it has been connected with the activities of the Interdisciplinary team for systems of expression and communication in art [Mezioborový tým pro vyjadřovaci a sdělovaci systémy v uméni]. In the 70s and 80s, a group of musicologists worked in this team, which was later called the "Prague team for music semiology". The core of this group were Jaroslav Volek (1923-1989), Jaroslav Jiránek (1922-2001), Jiří Fukač (1936-2002) and Ivan Poledňák (1931-2009). The initial wave of enthusiasm and a broader interest in this kind of research was replaced by a gradual cooling off during the 90 s. It seems now that music semiology stands at the periphery of musicologists' interest, while having the advantage of an "insiders' fellowship". Such a statement may sound exaggerated, but still the absence of references in scholarly writings or the frequency of papers in conferences rather support such pessimistic statements. Though the semiotic orientation of the Prague team gradually dissipated and the team itself fell apart through the successive deaths of its members, these succeeded during more than 12 years in creating an individual conception of musical semiotics. The members of the team described it in a range of studies in periodicals, books and dictionary entries. Jiř́ Fukač and Jaroslav Jiránek frequently reported on it at foreign conferences. Jiří Fukač attempted to explain the issue of music communication in his study Nomenclature of Music Communication [Pojmoslovie hudobnej komunikácie] ${ }^{2}$. Jaroslav Jiránek presented his individual approach to semiology especially in his book Mystery of Music Meaning [Tajemství hudebního významu] ${ }^{3}$. A summarizing study Musical Semiotics: A Report from Prague by Ivan Poledňák (1990) presents information in a form accessible for an English-speaking public. The three-volume publication

2 FUKAČ, Jiří. Pojmoslovie hudobnej komunikácie. In $O$ interpretácii umeleckého textu 9, Nitra: Pedagogická fakulta, 1986, s. 199-285.

3 JIRÁNEK, Jaroslav. Tajemství hudebního významu. Praha: Academia, 1979. 
Foundations of Musical Semiology [Základy hudebni sémiotiky] ${ }^{4}$ became a canonic writing of Czech semiology. A huge list of authors and publications could follow and would certainly confirm the statement about the variety of the subject. But all the various interpretations are subject to a rule - the tradition they all follow and refer to. This tradition is very clear. One of the authors most frequently cited in these texts is Otakar Zich (1879-1934), a pupil of Otakar Hostinský (1847-1910) and one of Jan Mukařovský's teachers. Another source of inspiration is presented by the texts of the Prague Linguistic Circle, which since 1929 have kept on formulating the semiotics of works of art. Their theory followed the conception of language as a semiotic system, elaborated by Ferdinand Saussure (1857-1913). Semiology, as presented by the Prague structuralists, was intended to become a new science - a general methodological basis for the theory of the arts, which would offer important arguments as polemics against aesthetic theories that attempted to interpret a musical work in terms of direct (causal) relations with the author's individuality, with biographical facts (biographical method, the interpretation of a work by its author), with ideological trends of the time or with sociological methods. This new science would study its subject as a structure of signs and values. The substance of art is no longer made up by subjective impressions, but by words, tones, surface, line, colour. Also in post-war history the general semiology and theory of communication played the role of an arbiter in solving some controversial questions in musicology and especially in the aesthetics of music. In relation to the unprecedented expansion of interest in structuralist methodology in the social and natural sciences in the $60 \mathrm{~s}$, the word "structure" became one of the most frequently used terms. In accordance with the interwar tradition I mentioned a moment ago, music is interpreted as a sign in which the communicative function is dispersed or vague, rather as in, let's say, abstract art.

Let the following superficial characteristics be a confirmation of this assertion. Many non-semantic conceptions result from experience, according to which music draws attention to itself. Listening to it, we distinguish structurally more important parts that draw our attention. The Czech tradition to some extent conforms to this conception by introducing the binary pair of terms presentation - representation. If something should function as a sign, then it must draw attention to itself, as a figure does in relation to its background. These can for instance be motifs or themes from traditional music; these parts are thematized by their repetition. Presentation becomes a secondary function of a sign, in contrast to representation, which is a proper function of a sign, that is, to mean something other than itself. In Czech semiology, besides the attempt to classify the signs and types of representation, we also find such terms as interpretation, typified sign, subsign, metasign, paradigm, syntagm (these correspond to the terms langue, parole), content and meaning. Music signs are created to circulate, to be communicated. But to be communicable, it's necessary to solve the problem of their

4 FUKAČ, Jiří - JIRÁNEK, Jaroslav - POLEDŇÁK, Ivan - VOLEK, Jaroslav. Základy hudebni sémiotiky. Brno: Masarykova univerzita, 1992. 
transfer and comprehensibility. If we take a further step and connect the problems of sign and structure with the process of signal exchange, we find ourselves in the field of music communication, as it was defined in the course of the 70s for instance by Jiř́ Fukač: "Music, typologically, genetically [...] belongs to the family of types of sound communication. [...] Music is simply, by rule and by its essence, a communicatum, it acts as a message and contains information". Thus, Fukač to confirmed the sign and communication character of music.

In the 60s music analysis influenced by the intonation theory of Boris Asafiev (pseud. Igor Glebov, 1884-1949) became popular, as he formulated it for instance in his work Musical Form as a Process [Музыкальная форма как проиесс] $]^{6}$. In Czech musicology this type of analysis was developed by Antonín Sychra and Jaroslav Jiránek attempted to develop it into a comprehensive system. The goal of this method was to bridge the perceived disjunction between the content of a heard musical work as subjectivity and its structure as objectivity. This kind of analysis then attempts to interpret a work as a so-called content form. Also another point is indispensable for a semantic interpretation: it must be preceded by a syntactic (or material) study, that is, a description of the hierarchical structure of the musical work. In the Czech (Czechoslovak) variant of this kind of analysis, especially the modified Riemann "Funktionstheorie", motivic-thematic analysis was used (this was used and developed in the Czech scene from the 1920s). The use of these methods then predetermined the results of these analyses.

We can recapitulate by saying that music cannot function as a semantic system a priori. So Czech semiology attempted to construct a critique and correction of music reception as an analogy to natural language and of musicology as a "philology of music". Despite a certain resemblance to language, music functions differently. What is understood as clear and comprehensible while a music work is being heard, resists a notional interpretation on account of its unclear, or on the contrary, ambiguous, signification. Generally it can be said that the semantic situation of a musical work greatly accentuates precisely those problems that underlie the process of communication of natural language. The discussion is not only about the specific cultural nature of musical material, but first of all about the dependency of meaning on the individual message conveyed by specific musical forms, conventions and traditions: Oriental music has no meaning for a European, and moreover music has no meaning for an inexperienced ear. Similarly the question of denotation in music refers to the field of emotional and value relationships, hardly comprehensible in terms of notions. Ambiguity, vagueness of meaning at various levels, and especially the dependence of meaning on a concrete realization of the work, are crucial in the case of music. Despite indisputable successes, musical semiology provokes many objections. We can for instance

5 FUKAČ, Jiří. Mýtus a skutečnost hudby: traktát o dobrodružství a oklikách poznání. Praha: Panton, 1989, s. 215-16.

6 АСАФЬЕВ, Борис Владимирович. 1930, 1947. Музыкальная форма как процесс. Москва: Государственное музыкальное издательство, 1947. 
ask if the fact that musical structure possibly functions as a sign, has any deeper significance for understanding the essence and function of music. And also the introduction of new terminology or use of excessive statistical and logical apparatus often leads to trivial, banal or expected results. (Such interpretations may even lead to the disappearance of the work as an artefact.)

Ordinary interpretations of Asafiev's theory for instance have often forgotten its psychological aspect, according to which a work should create causal relations which in the process of listening can be perceived as a logical form, penetrable according to the abilities of the listener. Musical analysis then funcions as a graphic representation of the way we perceive the work. The understanding of a musical work as a comprehensible unity leads from sections small enough to be registrable by musical memory, towards a compound unity. The quality of the hidden relations is the business of the listener, who seeks the original orientation of the work and determines its value.

What is Czech/Czechoslovak music semiology then like? This question must evidently remain unanswered. It would be daring to voice a verdict in the end, especially while it has not yet become merely a matter of the past, and while its future remains uncertain. None of us, who have been students under the abovementioned pioneers of this subject, have yet found enough courage or motivation to develop this tradition, which is without question rich in inspiration. But musical semiology will evidently survive as one of the methods that have determined the character of Czechoslovak musicology.

Lubomír Spurný (spurny@phil.muni.cz), Ústav hudební vědy, Masarykova univerzita, Arna Nováka 1, 60200 Brno.

\section{ABSTRACT CZECH MUSIC SEMIOLOGY}

The Preliminary study deals with the history of the Czech music semiology. This type of aesthetics theory was developed in Czechoslovakia from the end of the 50s. Since the 70s it has been connected with the activities of the Interdisciplinary team for systems of expression and communication in art. In the 70s and 80s, a group of musicologists worked in this team, which was later called the "Prague team for music semiology". The core of this group were Jaroslav Volek (1923-1989), Jaroslav Jiránek (1922-2001), Jiří Fukač (1936-2002) and Ivan Poledňák (1931-2009). The initial wave of enthusiasm and a broader interest in this kind of research was replaced by a gradual cooling off during the $90 \mathrm{~s}$. It seems now that music semiology stands at the periphery of musicologists' interest, while having the advantage of an "insiders' fellowship". Such a statement may sound exaggerated, but still the absence of references in scholarly writings or the frequency of papers in conferences rather support such pessimistic statements. Though the semiotic orientation of the Prague team gradually dissipated and the team itself fell apart through the successive deaths of its members, these succeeded during more than 12 years in creating an individual conception of musical semiotics. The members of the team described it in a range of studies in periodicals, books and dictionary entries. 


\section{Key words}

Music semiology, Czech music, aesthetics, musical structure, presentation - representation, sign, meaning

\section{Bibliography}

АСАФЬЕВ, Борис Владимирович. 1930, 1947. Музыкальная форма как прочесс. Москва: Государственное музыкальное издательство, 1947.

FUKAČ, Jiří. Pojmoslovie hudobnej komunikácie. In O interpretácii umeleckého textu 9, Nitra: Pedagogická fakulta, 1986, s. 199-285.

FUKAČ, Jiří. Mýtus a skutečnost hudby: traktát o dobrodružství a oklikách poznání. Praha: Panton, 1989.

FUKAČ, Jiří - JIRÁNEK, Jaroslav - POLEDŇÁK, Ivan - VOLEK, Jaroslav. Základy hudební sémiotiky. Brno: Masarykova univerzita, 1992.

JIRÁNEK, Jaroslav. Asafjevova teorie intonace, její geneze a význam. Praha: Academia, 1967.

JIRÁNEK, Jaroslav. Tajemství hudebního významu. Praha: Academia, 1979.

KARBUSICKÝ, Vladimír. Grundriss der musikalischen Semantik. Darmstadt: Wissenschaftliche Buchgesellschaft, 1986.

MUKAŘOVSKÝ, Jan. Kapitel aus der Poetik. Frankfurt a. M.: Suhrkamp, 1967.

POLEDŇÁK, Ivan. Musical Semiotics: A Report from Prague. Theory Only, 1990, no. 6, s. 1-13.

SYCHRA, Antonín. Estetika Dvoř́kovy symfonické tvorby, Praha: SNKLHU, 1959.

VOLEK, Jaroslav. Hudební struktura jako znak a hudba jako znakový system. Opus musicum, XIII/5, 6, 10 (1981), s. 129-142, 161-174, 289-295. 